\title{
“Prizrenli Bir Şair" Zeynel Beksaç ve Şiiri
}

\section{Mehmet SAMSAKÇI}

\author{
$\ddot{O} \mathbf{z}$
}

\begin{abstract}
Günümüz Kosova Türk şiirinin önemli temsilcilerinden olan ve sanatın pek çok alanında dikkate değer çalışmaları bulunan Zeynel Beksaç, 1970’lerden günümüze kadar şiiri hiç bırakmamış, yaklaşık 50 yllık süreçte Rumeli'nin Türkçe nöbetçilerinden birisi olmuştur. Geçtiğimiz yll, daha önce kitaplarına giren ve girmeyen şiirlerinin büyük bir kısmını Rumeli! O Benim İşte adıyla yayımlayan Beksaç, aşk, tabiat, sevgi, dostluk, barış, insanın dünya içerisindeki konumu gibi evrensel temaları ustalıkla kullanmış, özellikle Türklerin, oldukça zor ve çetin bir bölge olan Balkan coğrafyasiiyazidaki kimlik ve kişilik mücadelesini, Türkçe ve Türklük davasını ustaca mısralarıyla işlemiştir, dillendirmiştir. Bu çalışmada Zeynel Beksaç'in kişiliği ve estetiği üzerinde durulacak ve çocuk şiirleri dışındaki şiirlerinin kronolojik ve tematik tahlili yapılacaktır.
\end{abstract}

Anahtar kelimeler: Zeynel Beksaç, Kosova ve Balkan Türk Şiiri.

\section{“A Poet From Prizren” Zeynel Beksaç and His Poetry}

\begin{abstract}
Zeynel Beksaç, who is one of the important representatives of contemporary Kosovo Turkish poetry and who has done remarkable work in many fields of art, has been one of the Turkish proponents of Rumeli for almost 50 years. Beksac has published a large part of his past poetry, which has been and is not in his books before, in this book: Rumeli! O Benim İşte. Zeynel Beksaç has skillfully used universal themes such as love, nature, friendship, peace, human being's position in the world. Beksac described the identity and personality struggle of the Rumeli Turks living in the Balkan region, a very difficult region and expressed the love of Turkish profoundly. In this article, the personality and aesthetics of Zeynel Beksaç will be emphasized and chronological and thematic analyzes of poems outside of child poetry will be done.
\end{abstract}

Key words: Zeynek Beksaç, Kosova and Balkan Turkish poetry.

\section{Giriş}

Bu çalışmada, Rumeli'de Türkçe nöbeti tutan, sadece Türkçe yazmakla, yaşamakla kalmayıp evlâd-ı Fatihân olan hemşehrilerini Türkçeye davet eden, zor şartlar ve hatta imkânsızlıklar altında Türkçem adlı bir dergi de çıkaran, Kosova başta olmak üzere çeşitli Balkan ülkelerinde ciddî ve samimî diledebiyat faaliyetleri yapan Kosova Türk Yazarlar Derneği'nin başkanlığını da deruhte eden Beksaç'ın şair kimliği, şiiri, özellikle de en hassas noktası olan Türkçesi ele alınacaktır.² Zeynel Beksaç bir dönem Yugoslavya, şimdi de Kosova Türk şiirinin en önemli şairlerinden, yani dil işçilerinden birisidir.

\footnotetext{
1 Doç. Dr., İstanbul Üniversitesi, Edebiyat Fakültesi Türk Dili ve Edebiyatı Bölümü, Yeni Türk Edebiyatı Anabilim Dalı, samsakci@istanbul.edu.tr [Makale kaylt tarihi: 2.7.2018-kabul tarihi: 15.8.2018]

Zeynel Beksaç’ın Sevginin Rengini Arıyorsanız, Kavak Uyur mu?, Önce Sevgiye Doğar Günes ve Gökkuşă̆ında Salınan Çocuk başlıklı kitaplarında yayımladığı çocuk şiirleri de varsa da biz bu çalışmada bu şiirlere değinmeyeceğiz. Bu şiirlerin "çocuk edebiyatı" bağlamında ayrıca incelenmesi gerekmektedir.
} 
Zeynel Beksaç, 21 Şubat 1952'de, aslı “Pür-zerrin” (altın dolu, altın gibi değerli) olan, Sultan 1. Murad'ın ebedî istirahat-gâhı Kosova'nın güney-batısında bulunan, Rumeli şehirleri denince zihinlerde oluşan imaja en yakın şehir Prizren'de doğar. Bu Prizrenlilik önemli bir noktadır zira tarih içerisinde Prizren'de doğan her çocuk potansiyel bir şair olarak kabul edilegelmiştir. Bugün Üsküp’te medfun bulunan, sadece Türkler, Arnavutlar, Boşnaklar değil Makedonlar tarafından dahi Gazi Baba adıyla anılan (ismini büyük bir semt belediyesine de veren) meşhur tezkireci Âşık Çelebi, her Prizrenli bebeğin, bir şair namzedi olduğunu şöyle ifade eder Meşâirü’ş-Şuarâ'sında:

"Rivayet ederler ki, Prizren'de oğlan doğsa adından akdem mahlas korlar, Vardar Yenicesi'nde doğan oğlan baba diyecek vakit Farisî söyler, Priştine'de oğlan doğsa diviti belinde doğar, derler. Binâenalâzâlik, Prizren şair menbaı, Yenice Farisî ocağı ve Priştine kâtip yatağıdır.”3

Beksaç, ilköğreniminden sonra bir süre hukuk tahsil ettiyse de kısa sürede bu formasyonu terk ile gazeteciliğe yöneldi. Balkan Türklügü ve Balkan Türk matbuatında çok önemli bir yeri olan, esasında her Balkanlı Türk şairi, yazarı, gazetecisi, en kısa tabirle "entelektüeli” için bir ocak vazifesi gören Tan Gazetesi’nde, Priştine Radyosu'nda ardından da Priştine Televizyonu'nda çalıştı. Radyo ve televizyonda çeşitli kültür, sanat, edebiyat programları hazırladı. Bu mesai, kendisinin verdiği bilgilere göre 1974’ten, Yugoslavya’nın tam anlamılla dağıldığı 1999'a kadar sürdü.

1912'den, yani Osmanlı'nın Balkan topraklarını kaybetmesinden ve devlet olarak bu coğrafyadan çekilmesinden sonra, Üsküplü şair Yahya Kemal'in tabiriyle "hicretlerin bakiyesi" hicranlı insanlar hâlini alan Rumeli Türkleri, bu zor coğrafyada tutunmak için dillerine, kültürlerine ve kimliklerine sarılmışlardır. Bu anlamda Tomurcuk, Sevinç gibi çocuk dergilerini; Birlik ve Tan gibi hâkim millet iken azınlık durumuna düşmüş, düşürülmüş bir toplumu zinde ve ayakta tutan süreli yayınları çıarmışlar, engellemelere rağmen çok sayıda dernekler kurmuşlardır. Zira "derlenmezlerse" dağılacaklarını çok iyi biliyorlardı. ${ }^{4} \mathrm{Bu}$ anlamda Zeynel Beksaç da kadim bir dernek, aynı zamanda donatıcı bir mektep, pişirici bir ocak olan Doğru Yol Türk- Kültür Sanat Derneği'nin faaliyetlerinde yer aldı ve Doğru Yol Dergisi’nin ilk yedi sayısını çıkardı. Daha sonra Filiz ve Çı̆̆ dergilerinin yayımlanmasına katkı sundu. Beksaç bütün bu kültür-sanat ve edebiyat faaliyetlerinin yanında resim ve müzikle de ilgilendi ve bu alanlarda da önemli başarılara imza attı.

Zeynel Beksaç'ın eserleri şunlardır: Gurur Duy Sen XX. Yüzyıl (Tan Yayınları-Priştine 1980), Sevginin Rengini Arıyorsanı (Sevinç Yayınları - Üsküp 1982), Düşünce Usa Durmadı Daha (Sesler Yayınları Üsküp 1984), Kavak Uyur mu? (Sevinç Yayınları- Üsküp 1987), Önce Sevgiye Doğar Güneş (Tan Yayınları- Priştine 1995), Gökkuşağında Salınan Çocuk ( T.C. Kültür Bakanlığı- Ankara 1997), Vurmazsam Nâmerdim (Bireysel yayın, 1997), Mehmetçik Kosova'da (Raif Kırkul'la birlikte - Prizren 2002), Sevda Eskizleri (Azeri Türkçesiyle) (Vektor Yayınları- Bakü 2006), Resim Kültürü 2, Ders Kitabı, 2006, Priştine), Resim Kültürü 4, (Ders Kitabı, 2007, Priştine), Görsel Sanatlar 7, (Ders Kitabı, 2008, Priştine.) 5

3 Âşık Çelebi, Meşâirü’ş-Şuarâ (Haz: Filiz KILIÇ), İstanbul Araştırmaları Enstitüsü Yay., İstanbul 2010, s. 904.

$4 \quad$ Yugoslavya Krallığı ve Tito Yugoslavya'sı dönemlerinde Türklerin kurdukları dernekler, yayımladıkları dergi ve gazeteler ve en geniş mânâsında, arka arkaya gelen nesillerin oluşturdukları edebiyat hakkında bkz. Dr. Abdülkadir Hayber, Makedonya ve Kosova Türklerinin Edebiyat, Kurgan Edebiyat, Ankara 2001; Mustafa İsen, Varayım Gideyim Urumelïne: Türk Edebiyatının Bakan Boyutu, Kapı Yay., İstanbul 2009; Dr. Taner Güçlütürk, Kosova Türk Edeb̂̂ Yaratıcılğ̆ı, Baltam Yay., Prizren 2014, s. 10-21. (Bütün kaynakçasıyla beraber)

$5 \quad$ Zeynel Beksaç'ın hayatı ve sanat-matbuat alanlarındaki tüm faaliyetleri hakkında birinci elden bilgiler için bkz. Zeynel Beksaç, Rumeli! O Benim İşte, (Toplu Şïrleri 1971-2017), Türkçem Yay, Prizren 2017, s. 6-10. Zeynel Beksaç’ın Düşünce Usa Durmadı Daha ve çocuk şiirleri hariç bütün şiirlerini toplayan bu kitapta şair ve şiiri hakkında yazılan deneme ve makaleler, şairle yapılan röportajlar vs. de yer almaktadır. Bu yüzden çok sık kullanacağımız bu eseri, bu çalışmada 
Memleketi Kosova'nın maruz kaldığı savaşlar, çatışmalar, dolayısıyla yokluklar hatırda tutulursa çok mücadeleci ve velut bir sanat adamı olduğu rahatlıkla görülebilecek olan Beksaç'ın şiir dünyası ve şiirleri form ve içerik bakımından oldukça zengindir. Bu şiirler, tematik bir incelemeye tâbî tutulursa çocukluğa yani sâfiyet ve masumiyete özlem, tabiat ve hayat coşkusu, en geniş mânâsıyla aşk, gençlik, dostluk temlerinin, sosyal eleştirinin ön plânda olduğu görülür. Fakat bizce Beksaç şiirinin en baskın temi Türkçe ve Rumeli Türklü̈̆ü̈dür. Bu yüzden bu çalışmada biz Zeynel Beksaç’in şiir dünyasının genel özelliklerine ve baskın unsurlarına panoramik bir bakıştan sonra özellikle bu şiirlerdeki Türkçe aşkı, ısrarı ve vurgusuna odaklanacağız.

Beksaç’ın şiirleri Rumeli! O Benim İşte (Toplu Şiirleri 1971-2017) başlı̆̆ altında yayımlanmadan önce Gurur Duy Sen XX. Yüzyıl, Düşünce Usa Durmadı Daha, Çetrefil Sevda ve Vurmazsam Namerdim isimli kitaplarıyla okurla buluşur. (Beksaç, Josip Broz Tito hakkında yazdığı şiirlerden oluşan Gurur Duy Sen XX. Yüzyıl'ı Toplu Şiïler'e dâhil etmemiştir) Bu kitaplardan sonra yazılan ya da bir şekilde bu kitaplara girmeyen şiirler de Toplu Şïrler'e eklenmiştir.

Beksaç şiirine kronolojik ve tematik bir perspektifle yaklaşmadan önce Toplu Şiirler'in başına konan mısraları söz konusu etmenin yararlı olacağı kanaatindeyiz. ("Rumeli! O Benim İşte” başlıklı şiirin ilk mısralarıdır bunlar.) Zira kitabın iç kapağında, Beksaç’ı kubbeli, alemli ecdad yâdigârı bir binanın önünde "ayakta" gösteren bir fotoğrafın altında, bir epigraf şeklinde yer alan bu mısralar hem Beksaç'ı hem de Beksaç'ın şahsiyetinde tün Balkanlı Türk şairlerinin psikolojisini, mantalitesini ve estetiğini vermekte, yansitmaktadır.

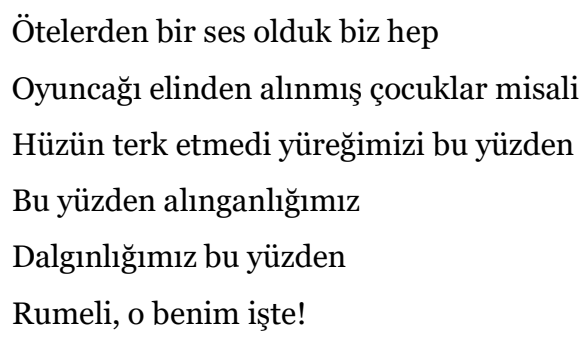

Balkan Türk edebiyatı hakkındaki ilk ve önemli eserlerin sahibi olan, aynı zamanda bu edebiyatı oluşturan eserlerin Türkiye'de basılması ve okunması konusunda değerleri gayretleri bulunan Prof. Dr. Mustafa İsen'in Ötelerden Bir Ses: Divan Edebiyatı ve Balkanlarda Türk Edebiyatı Üzerine Makaleler 6 isimli eserinin başlığına bir gönderme mahiyetini taşıdığını düşündüğümüz bu mısralar, Zeynel Beksaç'ın kendisini sunuş biçimi ve tarzının bizce en net ifadesidir ve şüphesiz Türkiye'ye bir sesleniştir. Bu seslenişte hüzünle karışık bir arz-ı hâl edası hâkimdir. “Ötelerden bir ses” olmak, Türkçeye, Türk şiiri ve edebiyatına, Türk kültürü ve medeniyetine suyun öbür yakasından, Rumeli'den eklemlenmeyi, bağlanmayı aynı zamanda da "öte” olarak kabul edilmeye dair bir sitemi de işaret eder. Önemine binaen Türk edebiyatı ve Türkiye karşısında Balkanlı Türk şairinin konumu ve durumu hakkında bazı dikkatler sunalım:

1912'den sonra Rumeli'de, özellikle Kosova ve Makedonya bölgesinde Türklük çok zor zamanlardan ve imtihanlardan geçmiştir. Önce Sırp-Sloven-Hırvat Krallı̆̆ı ve Yugoslavya dönemlerinde çok ciddî bir kimlik ve varlık mücadelesi sürdüren Türkler, Tito döneminde nisbî bir serbestlik elde etmişler (ki Beksaç’ın ilk şiir kitabı bu durumun bir yansımasıdır) özellikle 2. Dünya Savaşı sonrasında kurulan ve

boyunca Toplu Şïrler şeklinde zikredeceğiz. (M. S.) Beksaç'ın hayatı ve eseri hakkında birtakım tespit ve değerlendirmeler için ayrıca bkz. Güçlütürk, a.g.e.,, s. 172-202. 
büyük ve güçlü aynı zamanda büyük bir federatif devlet olan Tito Yugoslavya'sında Türkçe neşriyat yapabilmişler, kitaplarını bastırabilmişlerdir. Fakat sosyalist bir karakter taşıyan bu ikinci Yugoslavya'nın Türkiye karşısındaki tedirgin tutumu Yugoslavya Türklerinin Türkiye'deki fikir ve edebiyat hamlelerini gerektiği gibi ve yeteri kadar takip edebilmelerini imkânsız kılıyordu. Yugoslavya'daki edebiyat piyasasına Türkiye'den ancak bazı şairler girebiliyor, daha açık bir ifadeyle sadece sosyalist ve sol neşriyata vize veriliyordu. Bu sürece şahit olan ve hâlen hayatta olan pek çok Kosovalı ve Makedonyalı şair-edebiyatçı çeşitli vesilelerle bu gerçeği dile getirmekte, Yugoslavya'ya girmesine izin verilen Nazım Hikmet külliyâtının Türkçe edisyonunun kendileri, Türkçeleri ve Türklükleri için nasıl hayatî bir önem taşıdığını her fırsatta vurgulamaktadırlar. Bu anlamda ana vatandan uzakta, az ve azınlık durumunda kalan Rumeli Türklüğü, bu politik ve ideolojik baskılar yüzünden Türkiye için hep öte olmuş, ötelerden bir ses olmuştur. Bu “öte ses”, Türkiye’ye, Türkiye şairine, Türkiye'deki edebiyata uzaktan iştirak edebilmiş, seslenebilmiştir. Türkiye'nin bütün renkleriyle aktüel şiiri ve edebiyatı da ancak Yugoslavya'nın dağılmasından sonraki süreçlerde, kapıların geçek mânâda açılmasından sonra buralara girebilmiştir. Şunu da belirtmelidir ki 1990'ların ortalarında Bosna'da, sonunda da Kosova'da yaşayan vahşet ve dehşet Tito zamanlarını buralardaki Müslümanlara mumla aratmıştır. Ötelerden ses olmak, işte böylesi bir hasret ve gurbet öyküsünün kristalleşmiş hâlidir.7

Bu epigraf niteliğindeki mısraların devamında, "oyuncağı elinden alınmış bir çocuk” imajı karşımıza çıkar. Oyuncağı elinden alınan bir çocuğun mutsuzluğu tasavvur edilirse (çünkü oyuncağı, o çocuğun bütün dünyası, varlığı ve yaşama sevincidir) hâkimiyetini, gücünü, iktidarını yitiren ve azınlık durumuna düşürülen bir milletin ve milletin bir anlamda sesi olan şairlerinin nasıl bir hayal kırıklığına uğradıkları daha iyi anlaşılabilir. Kosova Türklüğü işte böylesine, kendi vatanlarında gurbeti yaşamış, kendi vatanında garip düşmüştür. Şiirde geçtiği gibi: "Hüzün bu yüzden terk etmemiştir yüreğini."

Beksaç, bizce her biri ayrı bir tahlil ve yorumu gerektiren bu mısraların deva "alınganlık ve dalgınlık" perdeleri açar. Bu alınganlık tek kelimeyle Türkiye karşısındaki bir aşırı hassasiyettir. Zira bütün bir millet adına ve bütün bir tarihî sorumluluk duygusu içerisinde öte'yi bekleyen Rumeli Türklügüu, Anavatan karşısında çok duyarlıdır. Anavatan'dan daima ilgi, saygı ve dikkat bekler. Türkiye Cumhuriyeti ve Türkiyeli Türklerin herhangi bir konudaki dikkatsizliği, bilgisizliği ya da ilgisizliği Rumelili Türkü derinden yaralar. (Estetik, "duyarlılık, hassasiyet" anlamına geldiğine göre en çok hissedenler, duyanlar olarak böylesi durumlar en çok şairleri rencide eder) Şiirde geçen alınganlık ve dalgınlık kelimelerinin arkasında böylesi realiteler, hisler bulunmalıdır. Kitaba adını da veren "Rumeli! O benim işte!" mısraının tevili ve tahlili için Yahya Kemal'in

"Yalnız duyan yaşar" sözü, derler ki, doğrudur

"Yalnız duyan çeker" derim, en doğru söz budur,

ve Mehmed Emin Yurdakul'un

Bırak beni haykırayım, susarsam sen mâtem et;

Unutma ki şâirleri haykırmayan bir millet,

Sevenleri toprak olmuş öksüz çocuk gibidir;

şeklindeki mısraları zannediyoruz ki kâfidir.

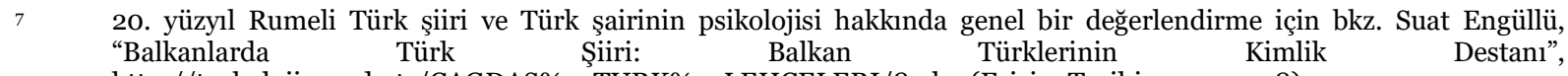
http://turkoloji.cu.edu.tr/CAGDAS\%2OTURK\%2OLEHCELERI/8.php (Erişim Tarihi: 01.07.2018) 
Şairin çocuk şiirleri dışındaki ilk şiir kitabı, yukarıda belirttiğimiz gibi Gurur Duy Sen XX. Yüzyıl başlığını taşımaktadır. Toplu Şïirler'e alınmayan bu 48 sayfalık kitaptaki şiirler, Balkanlardaki bütün topluluklar gibi Türklere de kendi dillerinde eğitim ve basın-yayın hakkı veren Tito'ya övgüler içerir. Şaire göre 20. yüzyıl, Tito gibi büyük bir liderin yaşadığı asır olmakla gurur duymalıdır. ${ }^{8}$

Beksaç'ın Düşünce Us'a Durmadı Daha başlığını taşıyan ikinci şiir kitabı, Birlik Yayınları arasında 1984’te, Üsküp'te basılmıştır.9 Mısralarının sayısı ve uzunluğu bakımından oldukça kısa, sadece 20 şiirin yayımlandığı bu kitapta Beksaç’ın şiirinin önemi merhaleler kaydettiği görülmektedir. Kendisiyle 1987 Temmuz'unda yapılan bir söyleşide, "Düşünce Usa Durmadı Daha kitabın, şïrine yeni bir soluk getirdi" şeklindeki yorumu "-Bu sav’n doğrudur. Ben de öyle düşünüyorum. Uzun bir suskun dönemim oldu. Dile gelemedim. Söyleyemedim. Söyleyemedimse, bende bir birikim oldu. Sonra birdenbire baktım ki yumak gibi çözülmeye başladı şïrim. Benim gerçek şïirim. Ya da beni gerçek ben eyleyen dizelerin döküntüsü... Bu şiir betiğ imde bir bakıma şïirimin özü sergilendi. Öteden beri beni ilgilendiren kişioğlu özyorumumla biçimlendi. Kişioğlunun yaşamak, insanca yaşayabilmek doğrultusundaki uzun ince yolunu yorumlamaya yaklaşım yaptım. Zor bir iş olduğunun bilincindeyim. Ama içimdekini de dökmeye çekinmedim. Bunu da akh taslamak anlaminda yapmadrm. İnsan benliğinin ne denli "” zor", hem de ne denli "kolay" korunabildiğini vurgulamayı amaçladım" cümleleriyle karşılar şair.10

Tito'nun 1980'deki ölümünden sonra hemen dağılmayan fakat kısa sürede dağılma emareleri göstermeye başlayan Yugoslavya döneminde, 1984'te yayımlanan bu eser, Beksaç'ın henüz tam anlamıyla Türkçe nöbetine durmadığı, aşırı toplumsal duyarlılık geliştirmediği bir sürecin ürünüdür. Bu kitapta daha çok düşünce, akıl, insanoğlunun kâinat içerisindeki yeri gibi soyut ve felsefî meseleleri ele alan şiirler söz konusudur. Kitabın başlı̆̆ı da bize bunu söyler. Kitabın - Nusret Dişo Ülkü’ye ithaf edilen - ikinci şiiri "İnsan ve Yaşamak Kavramı" şeklindeki başlı̆̆ı da bunu örnekler. (s. 140) Burada insanca, mertçe yaşamaya dair hükümler, yorumlar karşımıza çıkar. Bu şiir,

\author{
İç kapılarımız bir tek kendimize açıksa \\ Sindiremiyorsak onun bunun mutluluğunu \\ İçimize \\ Daha söze ne gerek \\ Yaşamak bir yanılgı demektir (s. 140)
}

mısralarıyla biter ki aslında burada bir sosyal eleştiri olmadığını ileri sürmek hata olur. 1970’ler, 1980’ler Türkiye'sinde neşredilen eserlerde gördüğümüz "Öztürkçe" akımı ya da modasının etkisinde yazıldığı anlaşılan "Sorgu" başlıklı şiirde "kin" duymadan yaşamanın değeri (s. 141), "Adam Sen de "isimli şiirde zamanın tapusunun kimsenin elinde olmadığı ve çıkar peşinde koşmanın anlamsızlığı vurgulanır. (s. 142) Bu kitabı oluşturan diğer şiirlerde de, benzer duygular, kavramlar, sorunsallar karşımıza çıkacaktır. Beksaç bu dönem şiirlerinde hayata, dünyaya, dünya içerisinde ve zamanın saltanatı altında insanın konumuna (görevine değil) eğilmiştir. Bu şiirlerde insana genel anlamda ve soyut plânda bir çağrı, bir davet söz konusudur. Bu davet, en geniş mânâsıyla "insanlığa" davettir. Bu şiirler, Yugoslavya'nın henüz dağılmadığı, Türklerin iyiden iyiye azınlık hâline gelmediği, Türkçenin Balkan dilleri arasında bir üvey

\footnotetext{
$8 \quad$ Bu kitaptaki şiirlerin genel bir tahlili ve Tito'nun Rumeli Türkleri tarafından nasıl algılandığı ve hatırlandığına dair bazı yorum ve değerlendirmeler için bkz. Güçlütürk, a.g.e., s. 177-182.

Bu eser, Toplu Şïrler'de, 1990 neşir tarihli Vurmazsan Namerdim (Ben Şairim) ve Çetrefil Sevda kitabından sonra yer almaktadır. (M.S.) Biz, kronolojiyi yani kitapların yayımlanma yılını esas aldığımız için bu çalışmada evvela Düşünce Usa Durmadı Daha'y inceliyoruz.

1o Şiirimde Güttüğüm Kavga Bireysel Değil, Topluca Bir Mutluluğa Yöneliktir”, (Konuşan: Şecaettin Koka), Toplu Şïrler, s. 627.
} 
evlât gibi görülmediği, toplumsal süreç ve şartların, şairi henüz sıcak kavgaya çağırmadığı bir zaman kesitinin ürünleridir. Bu yüzden bu kadar soyut ve geneldir. Fakat namus, ahlâk, samimiyet gibi konularda Beksaç hassastır ve bunların kaybını söz konusu eden ironik şiirler bu ikinci kitapta da karşımıza çıkar:

Satılmışız bir kere

Aka ak diyemeyiz

Hasan Hüseyin haklı da

Pardon

Biz bilmeyiz (“Açık Artırma Pazarı”, s. 144)

Aynı şekilde karşısındaki insana gönlünü açmayan, gönlünde yer vermeyen veya göstermeyenlerin bir "kapı" metaforu ile afişe edildiği “Kapılar Var ki” başlıklı kısa şiirde, durumu

Ben kapılardan hiç girmedim

Kapıcıklardan selâm verdim hep

Yaşama (s. 145)

mısralarıyla anlatır Beksaç. Kısaca belirtmek gerekirse bu küçük kitabın temel dinamiğini şairin benliği ve kâinat içerisindeki yeri ve sesi oluşturursa da eleştiri, ironi, çağrı, kin ve öfkenin insanı esir alışı (“Hayır, Sağır Değiller Bilirim” şiiri örneğin) gibi sosyal refleksler de önemli yere sahiptir.

Üçüncü kitap Çetrefil Sevda başlığını taşır ve Priştine merkezli Tan Yayınları arasında 1990'da basılmıştır. Çeşitli uzunluklarda, kimisi ayrı bölümler hâlinde kompoze edilen 37 şiirin yer aldığı bu kitapta da Zeynel Beksaç, kendisi olmayı, kendisi kalmayı başarmıştır. Daha ilk şiirde, "Bitmedi”de

Dört dörtlükte gözüm yok

Bana özgü olsun yeter ki (s. 88)

denmektedir ki bu mısralar bizce şairdeki "bu kendilik kaygısının en net yansımalarındandır. Fakat bu kendi olma, kendini anlatma, kendi çizgisini koruma konusu basit bir "kendine has"lık değildir. Beksaç, bir sanat eserinin, sanatçının iç dünyasını vermesi gerektiğini bildiği kadar, bu dünyayı aynı zamanda bütün insanların dünyası hâline getirmek zorundalığının da farkındadır. Anlatmak istediğimiz şudur: Bir okuyucu, eserini okumak suretiyle bir şairin dünyasına dâhil olmak, o dünya ile çoğalmak, zenginleşmek ister. Fakat farkında olsun veya olmasın aslında her okur, her dinleyici, her izleyici tecrübe ettiği eserin içerisinde biraz da kendisini arar. Bu bir anlamda bir empati, bir einfuhlung (özdeşleşme) sorunudur. Sanatçı bu gerçeğin farkına varmalı, kendisine ait hisleri, fikirleri, tecrübeleri bütün insanlı̆̆ın bir tarafı hâline getirebilmelidir. Aksi hâlde, hiçbir okuyucu, sadece bir kişiye has olan, bir kişiyi ilgilendiren bir deneyimi önemsemez. Bütün büyük klâsikler bu meseleyi hâlletmiştir. Örneğin Dostoyevski, Raskolnikov'la belli bir zamanda, Rusya'nın belli bir şehrinde yaşayan bir genci anlatır görünür. Ama o anlatımda Rus şehirleri, kültürü, toprağı da anlatılır. Ama aynı zamanda bütün insanlığın ezelî problemi olan suç, ceza, vicdan, ihtiras gibi kavramlara da yorumlar getirir. Ve okur, Raskolnikov'u hem tanımadığı, tanımaya değer bulduğu bir yeni dost gibi okur, hem onun fakir odasına, şehrine, çevresine girerek bir kültürü tanımış olur hem de insanlığın fitratında, hayatında, uzviyetinde olan bazı kavramlar hakkında yeni perspektifler edinir. Zeynel Beksaç da bir birey, Kosovalı bir Türk ama aynı zamanda büyük insanlık ailesinin bir üyesi olarak karşımızdadır. Kısaca biz Beksaç’ı okurken bir 20. yüzyıl şairini okuruz, aynı zamanda Balkanlılı̆̆ın ve Balkanlarda Türk olmanın nasıl bir şey 
olduğunu görürüz hem de kendi hayatımızda da tecrübe ettiğimiz bazı olgulara getirilmiş yeni yorumlar okuruz, bazı mısraların sanki biraz da bizim için yazıldığını düşünürüz. "Dizginler Bende Değil” başlıklı şiirin şu mısraları bu hissi kuvvetle vermektedir:

\author{
Durgun çaylar gibiyim \\ Bakarsın engin bir okyanus olmuşum \\ Kimi an bir palyaço \\ Kimi an bilge kesilirim \\ Dizginler bende değil \\ Azgın atlar yönüm biçmede (s. 89)
}

Çetrefil Sevda, Beksaç’ın onur, vicdan, kardeşlik, barış, sevgi (Bengi tarlada / Boy ver / Yücel / Sevgi sofrasinda al yerini "Bengi Tarla”, s. 102) ), dostluk, umut (Gün olur ki / Balıktan denizin / Böcekten toprağın / Haberini alırm / Başım üstünde kapkara bulutlar gezer / Ben gene de / Yartna umut gökkuşağını çizerim, "Gün Olur ki”, s. 100) erdem (Sözcük dağarcığımızda / Şemsiyeye gerek duymadan / Erdemle ipıslak varmahydık yarına", "Uyum”, s. 95; "Ve Erdemliği muştulayacaktı tan / Prhtılaşmayacak / Tazelenecekti kan, "Çetrefil Sevda", s. 96) gibi insanî hasletlere olan özleminin ve aşkının aynı zamanda bunları yitiren insanlara, insanlığa olan öfkesinin ürünü şiirlerin (Bkz. "Kuşatma", "Direnmek Eski Bir Tapınağındır Senin”, "Yılışıklar Konçertosu”) bol olduğu bir kitaptır.

Beksaç şiirinin seyri ve gelişimi bakımından, Çetrefil Sevda için mutlaka vurgulanması gereken noktalardan birisi de şairin bu kitapta kuşları (İlle de bir şeyler yıkılacaksa / Kırlangıçlar sürüsü / Üstüme yıkılversin ko "Öbür Uc", s. 129) ${ }^{11}$, dağları, tepeleri, yağmuru ("Beni Yağmura Çağır Unutma", s. 106; "Mor Düşün Sayıklamaları", s. 114), karı, kozmolojisiyle bütün bir tabiatla, kâinatla bütünleşme hâlinde olduğudur. Bu kitaptaki bazı şiirlerde Beksaç'ın, bütün hayvanat ve nebatatıyla tabiatın sesini ve kokusunu duyduğu, kendi ruhuyla tabiat arasında bir yol arayışında olduğu görülmektedir. Kendi zihni ve ruhuyla tabiat arasında bir uyum yakalayan şair "Uyum Ya Da Hava Durumunun Çizime Sığmayan Portreleri” başlıklı şiirinde yer ve gökyüzü arasında gidip gelmiş fakat bu tabiat odaklı şiirde modern insanın tabiat karşısındaki hoyratlık ve nankörlüğünü de göstermekten çekinmemiştir:

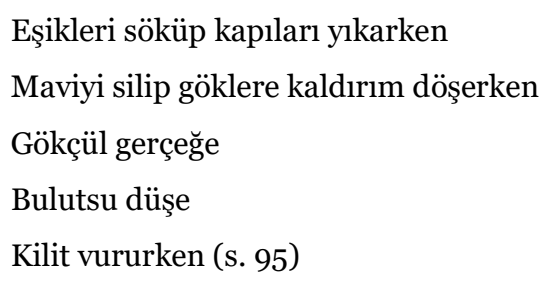

Bu tabiatla özdeşleşme, birleşme, bütünleşme kaygısı, kitaba adını veren şiirde de, bölümler hâlinde çalışılmış Çetrefil Sevda'nın ilk kısmında da söz konusudur. (s. 96) Burada bir örümceğin ağına dokunmayan, tozunu almak için ona el uzatamayan, bilâkis o örümceğim ağına karışan, onun ağında ă̆ örüp "ağlanan” bir şair vardır. Bu ağ çetrefil de olsa şairi câzibesiyle kendisine bağlar. Şair bu ağla kalmaz, "Irmak gibi çağlar", "bahardan bahara filizlenip dallanır, "sazına düzen vererek "bir türkü, bir hoyrat, bir nefes olarak" yürekten yüreğe yol alır, nihayet ahşap bir evin tavanında bir nakış olarak kalır. $\mathrm{Bu}$ şiirlerde çok canlı bir anlatım, çok başarılı bir perspektif söz konusudur. Sanıyoruz ki Tevfik Fikret ve Bedri Rahmi gibi ressam şairlerde gördüğümüz tasvir kuvveti ve imaj zenginliği, yine bir ressam şair

11 "İçimde Büyüyen Bir Güvercinin Uykusuzluktan Yakınışıdır" (s. 98) başlıklı bir şiir de vardır bu kitapta. 
olan Zeynel Beksaç’ta da vardır. Beksaç da şiirine kelime seçerken kelimelerin yerlerine ve renklerine dikkat etmektedir.

"Dut Kurusu'na Yanıtımdı»" başlıklı şiirde yer alan "Gel otobandan patika yola geçelim şöyle” (s. 120) mısraı da aynı şekilde tabiata, yani saflığa, tazeliğe, doğallığa dönme dürtüsünün bir ifadesi olarak anlaşılmalıdır.

Anadil Türkçe konusu ise yine Beksaç'in bu kitapta vazgeçemediği bir alandır. Oğlu Attila'ya hediye ettiği şiirinde, insanlığa ait çeşitli hâllerden, gerçeklerden, olgulardan, duygulardan bahsettikten sonra şair bahsi Türkçeye getirir:
Havasız susuz nasil olunmuyorsa
Dilsiz de olunmaz oğlum
Dilleri anadilinle seveceksin
Ancak dilinle tadını anlarsın
Yaşamda verdiğin kavganın
Türkçenle Yunus'a uzanır elin
O zaman gizi çözülür dilinin
Ve daha bir karışır dolarsın diline
Bunca âlemin (“Bengi Tarla”, s. 102)

Yeri geldikçe vurguladığımız üzere, Beksaç şiirinde bir leitte-motive şeklinde bir "kavga" metaforu karşımıza çıkmaktadır. Bu metafor, düz, basit, yalınkat bir etnik kavga şeklinde değildir. Balkanlardaki etnik orijinli çatışmaların yıllardır pek çok acılara sebebiyet verdiği, dolayısıyla Prizrenli şairi mustarip ettiği bir gerçektir. Fakat zannediyoruz ki Beksaç’ta asıl kavga, asıl mücadele, asıl gayret bir "insanlık davasını" kazanmak adınadır. Yukarıdaki mısralarda oğluna "yaşamda vereceği kavga"dan bahsetmişti. "Çılgın Düş" isimli şiirinde de çllgın bir düş kuran şair "tam bin yüzyılı aşarak" çok gerilere, her şeyin saf, herkesin masum olduğu zamanlara, insanoğlunun henüz kirlenmediği ve kirletmediği zamanlara gitmek ister. "İnsanlık" probleminde bağlar konuyu:
Ve yeni doğmuş
Bir bebek gibi saf
Kursak bir baştan
İnsanlık konutunu (s. 105)

Aynı evrensel perspektif, aynı kâinat vizyonu "Sonsuzluğa Pasaport Çıkardım Beni Bekle" şiirinde de kendisini gösterir. (Ki şiirin başlığı dahi, sınırsızlık özlemi ve aşkını çok iyi özetler)

Girdim ya bir kez

Evren kapısından

Bin kez vardım ya tadına

Sevgi bağının

Çă̆larım

Durmam (s. 119) 
Bütün dinler, insanı kâinat ve içindekileri karşısında sorumlu tutar. Özellikle İslâm, insanı müşerref kıldığı kadar mesul da görür. Felsefe ve sanat da asırlar boyunca insanın bu kaçınılmaz durumu üzerinde zihin yormuştur. Bütün büyük eserlerde, özellikle insanlığın iflâsa, felakete sürüklendiği modern sanatta şair, romancı, müzisyen, tiyatrocu, ressam ve yönetmenlerin "insanın mesuliyeti" sorununa dikkatle eğildiği görülmektedir. Nietzsche, Sartre, Kafka, Orwell gibi büyük sanatkârlar Avrupa başta olmak üzere sorumluluk duygusunu; tabiat ve "öteki” karşısındaki duyarlılı̆̆ını yitiren insanoğlunun çığlı̆̆ı hâline gelmişlerdir. Cemil Meriç de sanatçıyı, düşünürü "çağın vicdanı” olarak görür. Ahmet Hamdi Tanpınar, "insan mesuliyettir" der. İşte Beksaç’ın da bu sorumluluğu duyan bir şair olduğunda şüphe yoktur. Beksaç bu yönüyle, örneğin

Güzelliği savunan

Bir tek söz için

Nöbet durmaya

Var mısın (“Gözdağı ve Güzelliğin Savunması”, s. 115)

ya da

Sürüyü güttüm güdeli

Kavgaya gönül vereli

Ben bu lokmayı çiğneyeli

Hüznün duvarına kerpiç dizildim (“Bu Lokmayı Çiğneyeli”, s. 125)

mısraları gibi bütün insanlığın âlemdeki macerasını veren mısralarıyla büyük evrensel sanatçlar kervanına eklemlenmiştir.

Zeynel Beksaç, 1997'de yayımladı̆̆ Vurmazsam Namerdim (Ben Şairim) isimli kitabının girişinde "Hayata bakış açımla, yorumumla, içimdeki bilinen-bilinmeyen firtınalarla 30 yıldır şürde, resimde hep kendi akntım bulmaya, kendim olmaya; âhengiyle, rengiyle, biçimiyle, mesajıyla özgün bir havaya sahiplenmeye, ancak bu özelliklerle haz almayı, mutluluğun tadımlğ̆mı ucundan olsa bile yakalamayı başarabilirsem, benim için yaşam kazancı odur işte, diye bir görüşe sadık kaldım." demektedir. (Toplu Şiirler, s. 20) Bu, şairin, kendi sesinin ve nefesinin peşinde olduğunu bir kez daha vurgulaması demektir ki şiirde bu kendilik yani "hüviyet" problemi oldukça mühim ve esaslı bir meseledir. Zira ortak bir hafizayla yaşayan milletler, toplumlar, dolayısıyla bireyler, ortak bir dille konuşurlar. Fakat şairin işi bu herkese âit, harc-ı âlem, kolektif malzemeyle ferdî bir dil yaratmak, yakalamaktır. Hele Kosova, genel mânâda da Rumeli şairinin, yaşanan acılar, ıstıraplar, savaşlar, göçler, varlık mücadeleleri arasında kendi olabilmesi kolay bir şey değildir. Çünkü toplum, şairden sürekli "toplumsal" olmasını beklemekte, istemektedir. Bu, hakikaten üzerinde durulmaya değer bir konudur. Zira bir Rumeli şairi, "sadece” kendisi olamaz, kendisinden ibaret kalamaz. O bir şiir işçisi, fikir işçisi, bir timsal olmak zorundadır. Beksaç, başlığı çok manidar "Gerçek Sevdam Halkımdı Benim” şiirinde,

Sevdim ben de sevdalandım delicesine

Mehtaplı gecelerinde issiz sokaklarında Rumeli'nin

Sürmeli bir çift göz için kara sevda çektim de

Gerçek sevdam halkımdı benim hep (s. 39)

demektedir ki mısralar bu hâliyle hâliyle Namık Kemal'in 
Bâis-i şekvâ bize hüzn-i umumîdir Kemal

Kendi derdi gönlümün billah gelmez yâdıma

beytini hatırlatmaktadır.

Dikkat edilirse, aslında bu kitabın, kendisini halkı ve kültürü karşısında sorumlu hisseden bir şairin eseri olduğu daha başlıkta göze çarpar: "Vurmazsam Namerdim", ancak bir duruşu, tutumu, öfkesi, mücadelesi, gayreti olan bir insanın ifadesi olabilir. Beksaç, bu kitabının ikinci başlı̆̆ında vurmazsa niçin namert olmayı kabul ettiğini de açılamaktadır: Ben Şairim! Beksaç’ın özellikle dil, kültür, milliyet konularındaki bu sert ve kararlı tutumu bütün şiir serüveni boyunca devam etmiştir. Zira diğer bütün Rumeli şairlerinde olduğu gibi bu varlık kavgasında en büyük silâh dil olacaktır. Beksaç'ın da dili, yerine göre çektiği hançer, attığı ya da atmaya her zaman hazır olduğu okudur. “Türkçe'm Hep Siperim Oldu Ama” şiire dikkat edilirse bu varlık savaşında anadilin, zaman zaman şaire siperlik ettiği de fark edilir.

1997 neşir tarihli bu kitaptaki şiirler 1990'ların başlarında kaleme alınmış ya da tamamlanmış şiirlerden oluşmaktadır. Mutluluk, dostluk, çocukluğa özlem, yaşama sevinci bu şiirlerin de ön plândaki temleridir. Fakat Türkçe en önemli mesele olarak karşımızdadır. Şiirlerin sonlarındaki yazım zamanı ve yeri bilgilerine dikkate alınırsa bu şiirlerin, Prizren başta olmak üzere Struga, Ohri, Belgrad gibi Rumeli'nin çeşitli şehirlerinde kaleme alındıkları dikkati çekmektedir. Bu kitaba dair diğer bir özellik de şiirlerin pek çoğunun Balkanlı Türkleri söz konusu etmesi ya da Balkan şairlerine ithaf edilmesidir. "Süleyman Brina”, "Yunus Ağa”, "Mesut'un Şiiri”, "Vayçe’nin Şiiri”, "Sülo’nun Şiiri”, "Rido’nun Şiiri”, "Hasan Mercan'a”, "Suat Engüllü’ye” vs. Anlaşılmaktadır ki Beksaç, çocukluğundan itibaren tanıdığı, belirli özellikleriyle kendisi üzerinde tesiri bulunan kişiler bağlamında bir kültürü yakalamak ve duyurmak istemektedir. Şiirlerin bazılarının Beksaç'ın tanışma firsatı bulduğu ya da okuduğu şairlere hediye edilmesi ise Rumeli tarzı bir vefa, saygı ve kadirşinaslığın ürünü olmalıdır.

Bu kitaptaki şiirlere tematik bir perspektifle yaklaştığımızda, sosyal ve siyasal eleştirinin ön plânda olduğu görülür. 1981'de, Prizren'de yazılmış olan ve kitaptaki 3. şiir olan “Bana Eyvallah”ta Beksaç yıllar boyunca değiştirmediği bir tutumunu ortaya koyar: "Kravatsızlı".

Kaşık böyle
Çatal böyle tutulurmuş
Öyle değil
Böyle konuşulurmuş
Ha unutacaktım
Adam dediğin
Kıravatlı olurmuş
Tamam işte
Bu oyunda ben yokum
Bana eyvallah (s. 22)

Kravat takmamak basit bir tercih gibi görülebilir. Fakat kravatı bilinçle dışlama, reddetme, öteleme ve kravatlıları tenkit, aslında çok büyük bir simgesel değer taşır. Zira kravatı şuurlu şekilde reddetme aslında itaati reddetmedir. Kural koyucuların iktidarlarına bir çeşit başkaldırı şeklidir. Kravatın sembolik anlamları üzerine çokça zihin yormuş olan Antropolog David Graeber, "Kravatın paradoksu 
çözüldü” alt başlıklı yazısında kravatı "itaat" kavramı ve güçlü olma ya da görünme dürtüsüyle açıklar. ${ }^{12}$ İşte Beksaç'ın bu şiirdeki ve aynı kitaptaki “Soyut Gülüşe Çıkmalar” başlıklı mizahî ve ironik şiirindeki

Kıraç toprakta yeşermiş çayır

Irmakta Yunus balığı

Ylkıntılarda bile

Kuravatlıgil

Ütülügillerdendi

Ayna tarihi onunla başlardı

Aynalar müzesini de o kurmuştu

Uluslararası ayna yarışmasında

Bizzat ülkesinin temsilcisiydi (s. 74)

gibi mısralarındaki kravat antipatisi de tam bulunla yani düzenin, normların, makam ve mevki sahiplerinin ya da ortaklarının tanımladığı, dikte ettiği, sevdiği uslu, söz dinler adamın "kravatlı" oluşuyla ilgilidir:. Tanıyanlar bilir ki Zeynel Beksaç, şiirde olduğu gibi reel hayatta da kravata uzaktır. O da pek çok şair, yazar, ressam, müzisyen, yönetmen gibi fular'ı tercih eder. Zira kravat resmiyet ve görünüş demekse, fular sivillik ve görüş demektir. Bireysellik vurgusudur.

Esasında Beksaç, başkaları için ve başkalarına göre yaşamaya, toplumun ismi belli ya da belirsiz kurallarına; kolektif tercihlerin, kabullerin, kalıpların birey üzerindeki saltanatına karşıdır. O, bireyin, bireyin dünyasının, tercihlerinin bir anlamda savunucusudur. "Kibarlığa" da karşıdır. Fakat bu da basit ve yumuşak bir itaatsizlik ya da anarşistlik değildir. Beksaç'ın asıl savaşı zariflere, centilmenlere değil, "halka yüksekten bakan" sahte kibarlara karşıdır. "Kibarım" başlıklı şiirde şu mısralar yer almaktadır:
Yakana gül takıp
Geçmişsin aynanın önüne
Kimden yadigâr aldın kibarım
Halka böyle yüksekten bakmayı
Sorarlar bir gün sorarlar kibarım
Bunca yolu kat edip de ne yaptın
Çöl uzak kum bulunmazsa
Devekuşu misali
Başını nereye sokarsın (s. 72)

Bu önemli kitaba adını veren "Vurmazsam Namerdim: Ben Şairim” (s. 42) başlıklı şiirde de Beksaç’ın aynı tutumu, duruşu kendisini gösterir. Bu tutum ve duruş, ahlâk, namus, samimiyet ve doğruluktur. "Halk sözcüğünü bir kalkan gibi kullananlar", "şeytan sofrası kuranlar" ya da bu sofraya "kurulanlar", "sahte dostlar", "söze sahip çıkmayanlar", "insan harabesi nankörler"e karşıdır. Beksaç, bunlara vurmazsa namert olduğunu kabul edeceğini vurgulamaktadır

12 https://thebaffler.com/salvos/dickheads (Erişim tarihi: 30.06.2018) 
Dikkat edilirse Beksaç'ın aslında şiirlerinin tamamında bir çeşit içerik ahengi, tutarlılık görülmektedir. Şair dostluk, mutluluk, samimîlik, halk, Türkçe gibi, ilk bakışta birbirinden uzak gibi görünen kavram ya da duyguları aslında hep aynı anlamda, aynı şekilde kullanmaktadır. Yani Beksaç, kendisini dünya üzerinde konumlandırırken, dış dünyaya karşı tutumunu belirlerken bu kavramları beraber kullanmakta, bunları birbirinden farklı algılamamaktadır. Kısaca söylemek gerekirse dostluk, mutluluk, samimiyet, alçakgönüllülük gibi haslet ve meziyetler Beksaç'a ne ifade ediyorsa ya da Beksaç bunlardan ne anlıyorsa Türklük, Rumeli, Türkçe gibi kavramlar da Beksaç’ta aynı anlamı kazanmaktadır. "Türkçe'm Hep Siperim Oldu Ama” şiiri Beksaç’taki bu kavramlar ve değerler âhengini çok iyi yansıtır:

\author{
Ne kula boyun eğdim \\ Ne lokmaya kolayından geldim \\ Düzde yokuş tırmandım \\ Engelde kol gezdim varlandım \\ Türkçe’m hep siperim oldu ama (s. 43)
}

Yukarıda, , Beksaç'ın, kendi deyimiyle “Türkçenin Rumeli Yakası'nda” Türkçe söylemenin ve yaşamanın değerine fazlasıyla inandığını ve bu kitaptaki şiirlerde en çok Türkçeye odaklandı̆̆ını belirtmiştik. "Irgattım dilimin tarlasında /Bağında bağcıydım dilimin ("Gerçek Sevdam Halkımdı Benim”, s. 39); "Türküm hoyratum uzun havam / Bağlamam kemençem neyimsin / Yunus'um Mevlânâm Karacaoğlan’m / İçimdeki volkanın sönmez lavısın (“Gene Türkçe'm Üstüne Söylenmiştir”, s. 46-47); Kanadın' kırdılar kanadı / Kanat çırptın havalandın yaralı / Kırllp gücendin / Pes etmedin Dilgüvercinim / Özgürlüğe / Yengiye / Uçtun yürekli ("Dilgüvercinim”, s. 52); "Dede Korkut'ta Dilhançerim bilenir / Bundan özge kârı neyleyim ("Dil Hançerim”, s. 53) gibi mısralar şairin Türkçe sevdasıyla toprağa / zamana Türkçeyle tutunma gayretinin bazı örneklerindendir. Benzerleri Beksaç’ın şiir külliyatı içerisinde kolayca bulunabilecek bu Türkçe odaklı şiirlerde dikkat çeken şey, yukarıda da vurguladığımız gibi, Türkçe'nin varlık savaşında en büyük silah olduğudur. Bir Rumeli şairi, özellikle Zeynel Beksaç gibi hassasiyeti yüksek bir şair için bu durum hiç şaşırtıcı, hiç yadırgatıcı değildir. Türkçeyi ağzında annesinin ak sütü gibi "beyaz, temiz, mukaddes ve besleyici" gören Yahya Kemal ve Türkçeyi sesten bir bayrak gibi dalgalandırmak, taşımak isteyen Dağlarca gibi Beksaç da Türkçeyi neredeyse mukaddes ve mübarek kabul etmektedir. Yahya Kemal'in de Üsküplü bir Balkan çocuğu olduğu, Dağlarca'nın ise Nazım Hikmet’ten sonra Rumeli şairinin en çok sevdiği, okuduğu ve tanıdığı Türk şairi olduğu hatırlanırsa Beksaç’taki bu Türkçe duyarlığının arkasında bu iki büyük ustanın etkisinin bulunduğu düşünülebilir.

Bu eserde dikkati çeken unsurlardan birisi de Beksaç’ın Türk tarihine, tasavvufuna ve Türk dünyasına olan ilgisi ve sevgisidir. (Ki bu ilgi ve sevgi diğer eserlerinde de kendisini göstermiştir ki ayrıca çalışılmaya değer bir konudur) Zeynel Beksaç'ın şiirlerinde tertemiz Türkçesi ve dupduru itikadıyla Yunus Emre, bütün insanlığı kucaklayan hüsn-i nazarı ve Allah'ın rahmetine bütün insanlığı davet eden cömertliğiyle Mevlânâ, geniş Anadolu yaylalarının, bozkırlarının, engin dağların, ağaçların, tek kelimeyle, Türk’ün şahsiyetine bürünen ve Türk'e şahsiyetini veren tabiatıyla Anadolu'nun halk ozanı Karacaoğlan Beksaç şiirinin önemi motivasyon kaynaklarındandır. ${ }^{13}$

${ }_{13} \quad$ Muzaffer Uyguner bu duruma dair șöyle bir yorum yapar: “Beksaç, ülkemizdeki dil değisimlerini yakndan izlemekte ve yeni sözcükleri de ustaca kullanmaktadır. Sözcük seçiminde ve diziminde büyük çabalar harcadığı anlaşılmaktadır... Onun şïrinde, Türk mutasavvıflarmın yolunda olmasını, onlarm ardından giderek Tanrı sevgisini dile getirmenin gizi yatmaktadır... Beksaç’in şïrlerinin biçiminde belirli bir ölçü, sürekli bir dize kurgusu, şïrleştirme tutkusu yoktur... Böylece, kalıplar içinde kalmadan, çetrefil dediği o tanrısal sevgisini, insancıl sevgisini şürleştirmiştir..." "Şiiri İçin Dediler Ki”, Rumeli! O Benim İşte (Toplu Şïrler), s. 279. 


\author{
Biraz Yunus'um ben \\ Biraz Mevlâna \\ Biraz Veysel'im \\ Biraz Karacaoğlan \\ Sazımın düzeni Rumeli ayarlı \\ Biraz unutulmuş \\ Biraz efkârlı \\ Bundan kışlarım uzar \\ Gecikir baharım (“Biraz”, s. 54)
}

"Biraz" başlıklı bu kısa fakat kısalığı oranında tesirli şiirin yukarıya aldığımız ilk bendinde bu Anadolu'ya, Asya ve Anadolu tarzı Müslüman-Türk kültürüne bir seslenme, uzanma, erişme isteği ve psikolojisi dikkati çekmektedir. Ama aynı zamanda burada Rumelili olmanın, daha doğru bir ifadeyle Rumeli gibi zor bir coğrafyanın şairi, insanı olmanın, Anavatan'da, Türk bayrağı altında yaşayamamanın verdiği iç burkan bir his de sezilmiyor değildir. "Unutul-, efkâr, uzayan kışlar, geciken baharlar” gibi tabirler, bu duygunun, bu realitenin ifadesi olarak alınmalı, algılanmalıdır. ${ }^{14}$

Şiirleri Türk dünyası şiir şölenlerinde okunan, değişik Türk yurtlarında yayımlanan, Azerî Türkçesine çevrilen Zeynel Beksaç’ta, sadece Türkiye değil, dünyanın bütün coğrafyalarında yaşanan ve yaşatılan bir Türklük coşkusu da kendisini göstermektedir. Sanıyoruz ki dünyanın pek çok kıtasında, bölgesinde, yüzbinlerce kilometrelik coğrafyalarda "Türkçe" konuşan ve yaşayan Türk halkları, etrafı Slav ve Avrupa kültürüyle çevrilmiş bir coğrafyanın çocuğu olan Zeynel Beksaç’a büyük bir ufuk, büyük bir vizyon vermektedir. "Almatı'da Bir Yeşil Dal Olsam" başlıklı şiir işte bu duygunun, bu perspektifin, bu ufkun ürünü olan, bütün Türk dünyasını kucaklayan bir manzumedir.

\title{
Sonuç
}

Şiire ve diğer sanat-edebiyat çalışmalarına, büyük ve kadim bir kültür şehri olan Prizren'de çocuk denecek bir yaşta başlayan, çeşitli dernek çalışmalarında etkin rol alan, radyo, televizyon gibi kitlesel platformlarda Türkçe'nin ve Türk sanatının duyurulması, yaşatılması konusunda büyük emekleri olan, kitap çalışmaları yanında hâlen dernek ve dergi faaliyetleriyle Türkçe savaşını devam ettiren Zeynel Beksaç, 20 ve 21. yüzyl Kosova Türk şiirinin en velut kalemlerindendir. Çocuklar için yazdığı şiirler haricinde henüz Yugoslavya döneminde 4 şiir kitabı yayımlayan ve 2017 yılında, şiirlerini Rumeli! $O$ Benim İşte başlı̆̆ıla okuyucu ile buluşturan Beksaç, dostluk, vefa, barış, sevgi, hürriyet, samimiyet gibi evrensel temaları başarıyla işlediği gibi, Türkçe üzerine yazdığı şiirlerle de bir "varlık ve kimlik mücadelesinin” en etkili savaşçılarından birisi olmuştur. Beksaç’ın şiiri, dünyanın bir bölgesinde, belirli bir zamanda yaşamış bir bireyin, bir şairin iç dünyasını verdiği kadar, Kosovalı / Balkanlı bir şairin Türkçe ile hayata, toprağa ve zamana tutunma gayretlerini de aksettirir. Bu yönüyle Zeynel Beksaç’in şiirleri pek çok yönden okunmaya, değerlendirmeye, çözümlenmeye müsait zengin içerikli metinlerdir.

\section{Kaynakça}

Âşık Çelebi, Meşâirü’ş-Şuarâ (Haz: Filiz KILIÇ), İstanbul Araştırmaları Enstitüsü Yay., İstanbul 2010.

\footnotetext{
14 Anadolu'nun ve Rumeli'nin büyük söz ve mânâ erleri, ozanları Beksaç'ın daha önceki şiirlerinde de kendilerine yer bulmuşlardır. Çetrefil Sevda'da yer alan “Ayrım” șiirinde geçen Sazın gizine gönül bağlamışım ben / Pir Sultan demişim / Âşık Ferki demişim / Karacaoğlan demişim / Âşık Veysel demişim / Ve coşmuşum ırmağında türkünün (s. 124) mısralarında ya da bütünüyle "Mevlânâ'ca" şiirinde (s. 134) olduğu gibi.
} 
Beksaç, Zeynel, (2017), Rumeli! O Benim İşte, (Toplu Şiirleri 1971-2017), Prizren, Türkçem Yay.

Engüllü, Suat, "Balkanlarda Türk Şiiri: Balkan Türklerinin Kimlik Destanı", http://turkoloji.cu.edu.tr/CAGDAS\%20TURK\%20LEHCELERI/8.php (Erişim Tarihi: 01.07.2018)

Güçlütürk, Taner, (2014), Kosova Türk Edebî Yaratıcılığı, Prizren, Baltam Yay.

Graeber, David, (2015), "Dickheads: The Paradox of The Necktie Resolved" https://thebaffler.com/salvos/dickheads (Erişim tarihi: 30.06.2018)

Hayber, Abdülkadir, (2001), Makedonya ve Kosova Türklerinin Edebiyatı, Ankara, Kurgan Edebiyat.

İsen, Mustafa, (1997), Ötelerden Bir Ses: Divan Edebiyatı ve Balkanlarda Türk Edebiyatı Üzerine Makaleler Ankara, Akçağ Yay.

İsen, Mustafa, (2009), Varayım Gideyim Urumeli’ne: Türk Edebiyatının Bakan Boyutu, İstanbul, Kapı Yay. 